\title{
PERENCANAAN INSTALASI LISTRIK DENGAN MENGGUNAKAN HYBRID PADA RUMAH TOKO (RUKO) TIGA LANTAI DI TARAKAN
}

\author{
Imam Aprianur ${ }^{1}$, Sugeng Riyanto ${ }^{2}$ \\ ${ }^{1,2}$ Teknik Elektro, Universitas Borneo Tarakan, Tarakan, Kalimantan Utara, Indonesia \\ 1imam.aprianuregmail.com \\ ${ }^{2}$ sugeng@borneo.ac.id
}

\begin{abstract}
Basically the electrical installation is a series of inter-linkages with each other, and are connected or coordinated. In planning the required installation in accordance with the general requirements of the electrical installation (PUIL) and can lead to the use of materials to be used, with the Indonesian National Standard (SNI).

In planning the electrical installation using the Hybrid Photovoltaic System which is a supply of electrical energy with the use of solar radiation energy source that can be converted into electrical energy. By planning the electrical installation is a combination of two power supply, but from Solar (Photovoltaic Systems) and network electrical installation is supplied directly from the source PLN (Grid Connection)
\end{abstract}

Keywords - Electrical Installation, Hybrid Photovoltaic System.

Intisari- Pada dasarnya Instalasi listrik adalah suatu rangkaian yang saling keterkaitan satu dengan yang lainya, serta saling terhubung atau terkoordinasi. Dalam perencanaan Instalasi diharuskan sesuai dengan persyaratan umum instalasi listrik (PUIL) serta dapat mengarah pada pemakaian bahan yang akan digunakan, dengan Standard Nasional Indonesia (SNI).

Pada perencanaan instalasi listrik dengan menggunakan Hybrid Sistem Photovoltaic yang merupakan suatu penyediaan energi listrik dengan pemanfaatan sumber energi radiasi matahari yang dapat diubah menjadi energi listrik. Dengan perencanaan instalasi listrik ini merupakan penggabungan dua catu daya, melainkan dari Tenaga Surya (Sistem Photovoltaic) dan jaringan instalasi listrik yang disuplai langsung dari sumber PLN (Grid Connection).

Kata Kunci — Instalasi Listrik, Hybrid System Photovoltaic

\section{PENDAHULUAN}

Indonesia merupa kan salah satu negara yang mendapat sinar matahari sepanjang tahun. Artinya potensi pemanfaatan PLTS (Pembangkit Listrik Tenaga Surya) sangat besar. Hal ini tentunya merupakan salah satu alternatif yang sangat baik untuk mengurangi ketergantungan pembangkit pada sumber energi PT. PLN Tarakan yang semakin menipis. Sehingga perlu pemanfaatan sumber energy terbarukan salah satu adalah pembangkit listrik yang menggunakan energy terbarukan dengan hybrid sistem photovoltaic. Perancangaan dengan hybrid system photovoltaic merupakan penyediaan energi listrik yang sumbernya menggunakan energi terbarukan yaitu radiasi matahari. Sistem hybrid disini merupakan penggabungan dua catu daya yaitu catu daya tenaga surya (Sistem Photovoltaic) dan jaringan instalasi listrik pada gedung atau rumah tinggal yang disuplay dari sumber PLN (Grid Connection).

Instalasi listrik adalah suatu rangkaian yang keterkaitan satu dengan yang lainya, serta memiliki saling terhubung atau terkoordinasi. Pemasangan Instalasi listrik terikat suatu peraturan-peraturan dimana peraturan tersebut bertujuan untuk mengatur pemakaian bahan yang akan digunakan pada pemasangan instalasi listrik. Pemasangan instalasi listrik tersebut harus memenuhi standarisasi yaitu Standard Nasional Indonesia (SNI). Untuk standarisasi dibidang teknik listrik mengacu pada Internasional Electrotechnical Commission (IEC). Standard pemasangan instalasi listrik diindonesia merujuk pada standarisasi yang digunakan pada Standarisasi Perusahaan Listrik Negara (SPLN) atau Peraturan Umum Instalasi Listrik (PUIL) 2000.

Tujuan utama dari instalasi penerangan adalah memberikan kenyamanan pada jarak pandang mata. serta pekerjaan-pekerjaan yang memerlukan ketelitian, maka diperlukan penerangan yang mempunyai kuat penerangan yang cukup baik. Untuk memenuhi kebutuhan penerang pada instalasi listrik meliputi, faktor-faktor keindahan (Estetika), Kenyamanan (Comfortable) dan dari segi ekonomis maka ketentuan tersebut perlu diperhitungkan didalam perencanaan pada instalasi listrik, seperti halnya penerangan rumah tinggal, rumah toko, gedung perkantoran, gedung sekolah, hotel, gedung pameran, pabrik, serta gedung laboraturium dan lain-lainnya [2].

Faktor-faktor yang harus diperhatikan didalam perencanaan instalasi listrik untuk penerangan adalah: Pemasangan instalasi listrik harus memenuhi aturan antara lain:

\section{A. Kenyamanan (Comfortable).}

Untuk memberikan kenyamanan mata didalam menikmati atau melaksanakan sesuatu kegiatan tanpa adanya akomodasi yang berlebihan, yang dimaksud adalah memberikan jarak pandang mata yang baik dan kenyamanan kepada pemakainya. 
B. Keindahan (Estetika).

Selain faktor jarak pandang mata yang baik dan kenyamanan,diperlukan juga faktor keindahan yang mana kedua faktor tersebut dapat saling mendukung serta saling mengisi satu sama lainnya, sehingga dapat diselaraskan mengingat keduanya sangat penting.

\section{Ekonomis.(Economise).}

Fleksible adalah mudah untuk menyesuaikan sistem apabila adanya perubahan-perubahan atau pengantian pada suatu instalasi listrik. Investasi murah adalah dengan pemanfaatan instalasi listrik yang sebaik mungkin, untuk selalu diusahakan biaya semurah atau seefisien mungkin dengan pelayanan listrik yang sebaik-baiknya, yaitu dengan cara, Tidak menggunakan material atau peralatan instalasi yang spesifikasinya dan kegunaannya melebihi dari keperluan, kecuali apabila benar-benar lebih murah dan ekonomis dan Memenuhi persyaratan teknis.

\section{LANDASAN TEORI}

\section{A. Panel Surya (Photovoltaic)}

Panel surya photovoltaic adalah merupakan suatu alat yang dapat mengubah energi radiasi matahari menjadi energi listrik. Dalam sinar matahari terkandung energi dalam bentuk foton. Ketika foton ini mengenai permukaan sel surya, elektron-elektronnya akan tereksitasi dan menimbulkan aliran listrik. Prinsip ini dikenal sebagai prinsip photovoltaic [1].

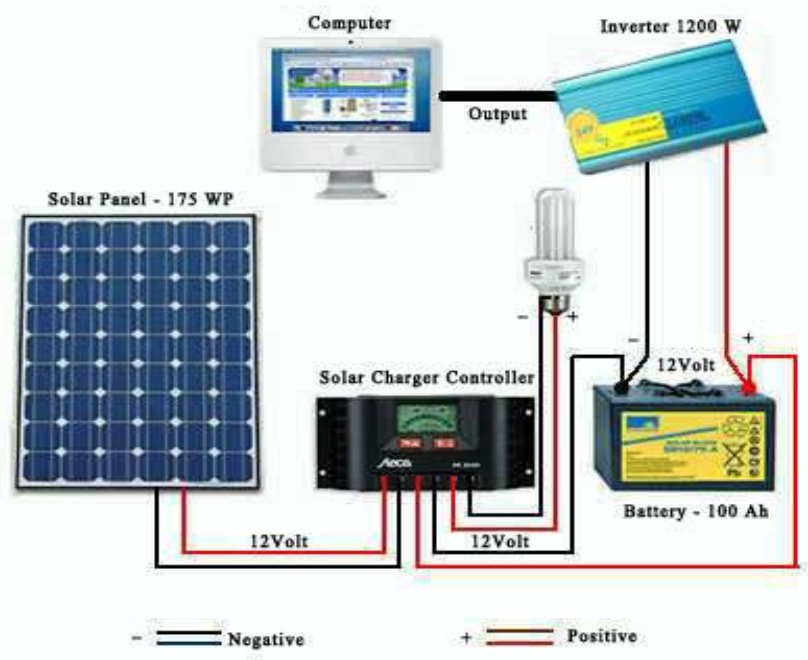

Gambar 1. Rangkain panel surya

\section{B. Modul Photovoltaic/Panel surya}

Kapasitas daya Modul Photovoltaic dapat diperhitungkan dengan memperhatikan beberapa faktor, yaitu kebutuhan energi sistem yang disyaratkan, insolasi matahari, dan faktor penyesuaian (adjustment factor). Faktor penyesuaian adalahpada kebanyakan instalasi Pembangkit Listrik Tenaga Surya (PLTS) [1].

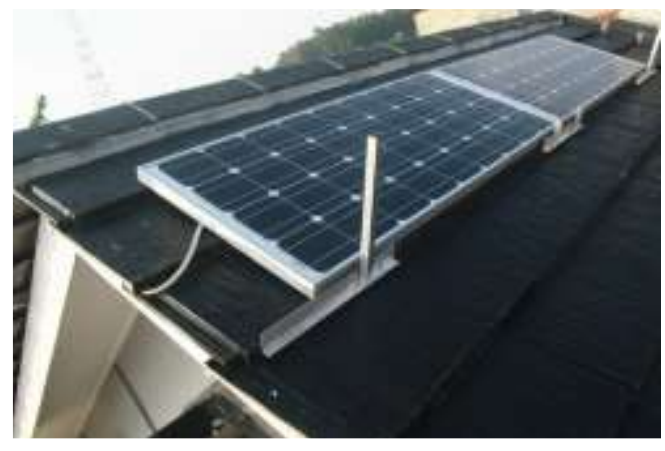

Gambar 2. Panel surya $100 \mathrm{Wp}$, di atas genteng

\section{Solar Charge Controller}

Solar controller adalah alat yang digunakan untuk mengontrol proses pengisian muatan listrik dari panel surya ke aki dan juga pengosongan muatan listrik dari aki ke beban seperti lampu, kipas angin, dll. Terdapat setidaknya dua jenis solar controller yaitu yang menggunakan teknologi PWM (pulse width modulation) dan MPPT (maximum power point tracking). Solar controller PWM akan melakukan pengisian muatan listrik ke aki dengan arus yang besar ketika aki kosong, dan kemudian arus pengisian diturunkan secara bertahap ketika aki semakin penuh.

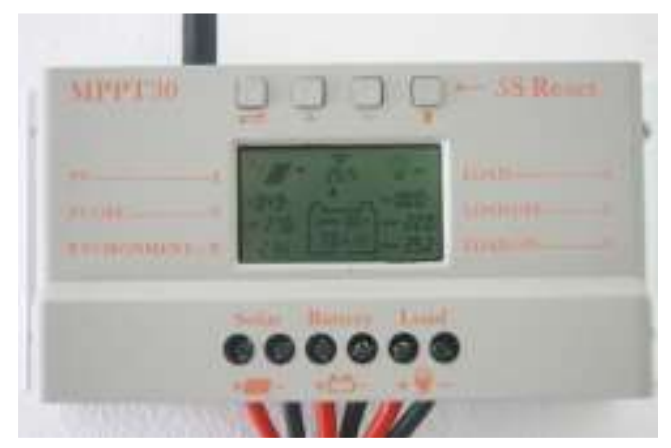

Gambar 3. Solar Charge Controller MPPT 12/24 Volt

D. Baterai

Baterai atau Aki yang biasa kita kenal adalah komponen sistem photovoltaic yang berfungsi menyimpan energi listrik yang dihasilkan oleh Modul Photovoltaic pada siang hari, untuk kemudian dipergunakan pada malam hari dan pada saat cuaca mendung. Aki yang digunakan pada sistem photovoltaic mengalami proses siklus mengisi (charging) dan mengosongkan (discharging), tergantung pada ada tidaknya sinar matahari. Secara garis besar aki dibedakan berdasarkan aplikasi dan konstruksi. Berdasarkan aplikasi maka aki dibedakan untuk engine starter (otomotif) dan deep cycle. Aki deep cycle biasanya digunakan untuk system Photovoltaic (solar cell) dan back up power, dimana aki mampu mengalami discharge hingga muatan listriknya tinggal sedikit. 

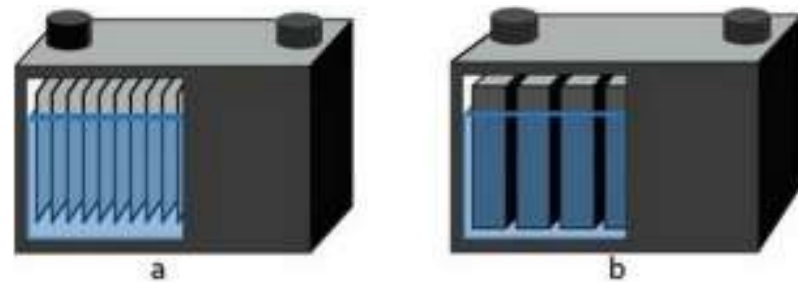

Gambar 4. Jenis aki starter (otomotif) (a) dan deep cycle (b)

Kapasitas suatu baterai menyatakan berapa lama kemampuannya untuk memberikan aliran listrik, pada tegangan tertentu yang dinyatakan dalam ampere hour (Ah). Kapasitas baterai dapat dinyatakan dengan persamaan sebagai berikut:

\section{E. Inverter}

Inverter adalah perangkat yang digunakan untuk mengubah arus searah $(D C)$ dengan tegangan sebesar 12 Volt .Alat ini diperlukan untuk perancangan SollarCell. Selain itu jika menggunakan inverter yang mengubah menjadi arus bolak balik ( $A C$ ) 220 volt, ini sesuai dengan listrik yang ada pada PLN sehingga dapat dikombinaska dengan instalasi listrik dengan menggunakan hybrid (gabungan listrik PLN dan Sollar Cell) dengan instalasi listrik yang sama.

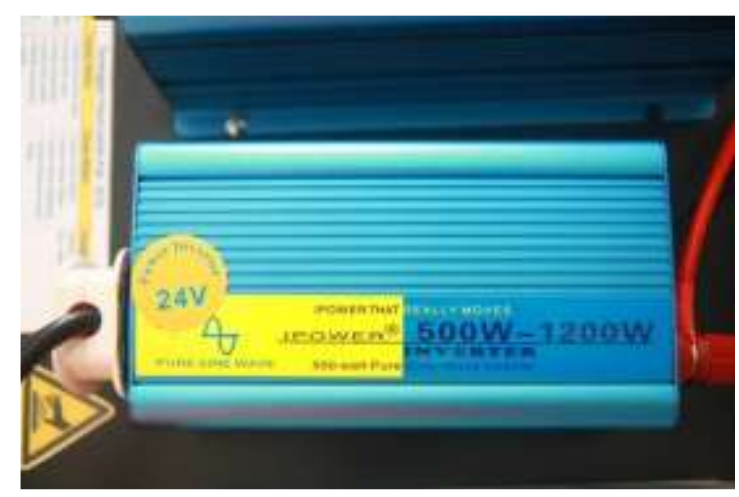

Gambar 5. Inverter 24 V 500-1200 W

\section{F. Modul Photovoltaic - Grid Connection (Jala-Jala PLN)}

Sistem Hybrid adalah gabungan atau integrasi antara catu daya jala-jala PLN (grid connection) dan tenaga surya (sistem photovoltaic). Modul Surya (module photovoltaic) adalah sumber energi dengan menggunakan rangkaian module photovoltaic, merupakan sistem pembangkit listrik alternatif dengan mengandalkan energi matahari sebagai sumber energi utama. Untuk dapat menghasilkan energi listrik sesuai dengan kebutuhan yang ramah lingkungan dan bebas folusi bagi penduduk perkotaan, baik perumahan, pertokoan, dan perkantoran.

Sistem Hybrid ini tetap berhubungan dengan jaringan PLN, melainkan dengan mengoptimalkan pemanfaatan energi module photovoltaic untuk menghasilkan energi listrik semaksimal mungkin, guna dapat mengurangi tagihan listrik rumah tangga, dan memberikan nilai tambah pada pemiliknya.

\section{G. Sistem Hybrid}

Sistem hybrid antara Modul Surya dan sumber listrik PLN, pada proses kendali Sistem hybrid yang menggunakan prinsip kerja satu arah, dalam satu waktu tertentu beban hanya disuplai oleh salah satu sumber, dengan system otomatis switch controller akan mengatur sumber yang akan menyuplai kebeban. Dimana ketika solar controller memutus aliran ke beban, maka relay secara pasif akan menghubungkan aliran ke listrik PLN. Yang artinya menggunakan listrik PLN dan Solar cell yang berganti secaraotomatis. Pada siang hari, kebutuhan energi listrik disuplai langsung oleh Modul Surya, dan malam hari atau jika kondisi cuaca mendung maka energi listrik disuplai oleh jaringan PLN. Hal ini dimungkinkan karena sistem ini tetap terkoneksi dengan jaringan PLN.

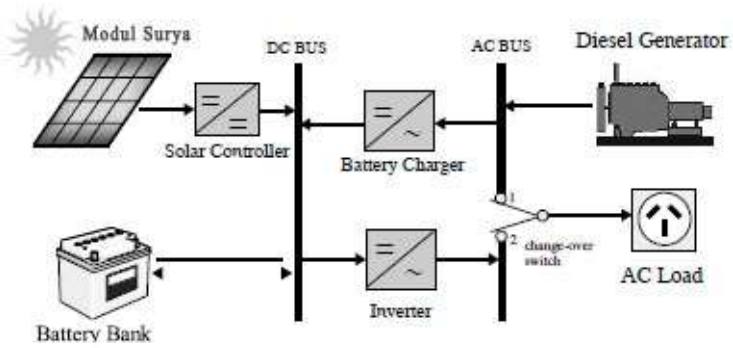

Gambar 6. Sistem Hybrid Grid Connection

Pada radiasi matahari yang diperlukan dalam perhitungan kapasitas modul adalah dimana pada radiasi bulan Januari 3,547kwh/ . Untuk mendapatkan kapasitas daya pada modul, yang diperlukan didalam perhitungan adalah jumlah jam kerja matahari, bukan besarnya radiasi pada matahari. Oleh karena itu pada radiasi bulan Januari, dibagi dengan Standart Test Condition yaitu 1000 W/m2.

Untuk memenuhi kebutuhan yang sesuai dengan kondisi dilapangan, maka digunakan sejumlah modul, sehingga diperoleh jumlah yang dbutuhkan. Dalam perencanaan ini digunakan modul yang berkapasitas 100 $\mathrm{Wp}$

\section{H. Instalasi Listrik}

Instalasi listrik adalah jaringan atau saluran yang rangkaiannya satu sama yang lain saling terhubung ke beban. Instalasi listrik terbagi beberapa golongan diantaranya adalah:

a. Instalasi domestik (rumah tinggal) adalah Instalasi listrik untuk rumah tinggal, rumah kontrakan, rumah susun .

b. Instalasi non domestik adalah instalasi listrik untuk sosial, bisnis dan publik:

1. Sosial: Rumah sakit, rumah ibadah, rumah panti sosial, rumah pusat rehabilitasi cacat, rumah (tempat asrama) pelajar milik pemerintah.

2. Bisnis: Perhotelan, perbankkan, pergudangan dan perkantoran pertamina.

3. Publik: Perkantoran pemerintah atau perkantoran perwakilan asing.

c. Spesifikasi dan tempatnya instalasi listrik terbagi dua diantaranya adalah:

1. Instalasi listrik didalam gedung. Instalasi listrik didalam gedung adalah instalasi listrik yang pekerjaannya meliputi: instalasi listrik pada rumah 
tinggal, instalasi listrik perkantoran dan instalasi listrik rumah sakit, dimana penerangannya meliputi setiap ruangan, teras, koridor dan lain-lainya.

2. Instalasi listrik diluar gedung. Instalasi listrik diluar gedung adalah instalasi listrik yang pekerjaannya diluar gedung yaitu instalasi listrik penerangan halaman rumah, taman, jalan dan lain-lainnya.

I. Perencanaan Instalasi Listrik

Perencanaan instalasi listrik adalah suatu rangkaian yang bertujuan untuk mengalirkan listrik guna memenuhi kebutuhan manusia. Dimana perencanaan tersebut merujuk pada suatu peraturan yang tercantum pada Peraturan Umum Instalasi Listrik (PUIL) 1977,1987 dan yang terbaru Persyaratan Umum Instalasi Listrik (PUIL) 2000, antara lain adalah:

1. Gambar situasi denah rumah atau bangunan yang akan dipasang jalur instalasi listriknya.

2. Diagram garis tunggal [3].

J. Peralatan Instalasi Listrik

Peralatan instalasi listrik yang digunakan didalam pesangan instalasi listrik adalah:

1. Benda isolasi

Berfungsi sebagai melindungi listrik yang mengalir pada konduktor/penghantar agar tidak bersentuhan dengan penghantar yang lain dan isolasi harus tahan terhadap panas, tidak mudah rusak.

2. Pipa instalasi

Pipa yang digunakan dalam pemasangan instalasi listrik adalah pipa pvc 5/8" dan pipa fleksibel.

3. Benda bantu.

Benda bantu dalam pemasangan instalasi listrik adalah kotak normal yaitu dos tempat sambungan kabel maupun tempat pemasangan saklar.

4. Saklar

Saklar adalah sebagai fungsi memutuskan dan menghubungan rangkaian listrik kebeban. Saklar terbagi dua macam yaitu saklar tunggal dan saklar seri.

5. Stop kontak/kontak-kontak bagi (KKB).

Stop kontak/kontak-konta bagi adalah peralatan listrik yang berfungsi sebagai penyambungan beban dengan sumber listrik [3].

\section{K. Intensitas Penerangan}

Intensitas penerangan ditentukan di tempat pekerjaannya akan dilakukan. Bidang kerja umumnya diambil $80 \mathrm{~cm}$ di atas lantai. Bidang kerja ini sebuah meja atau bangku kerja, atau juga suatu bidang horisontal khayalan, $80 \mathrm{~cm}$ di atas lantai. Intensitas penerangan yang diperlukan ditentukan oleh sifat pekerjaan yang harus dilakukan. Pada gambar 2.7 menunjukan intensitas penerangan untuk ruang dan jenis pekerjaan.

Intensitas penerangan $E$ dinyatakan dalam satuan lux, sama dengan jumlah $\mathrm{lm} /$. Jadi flux cahaya yang diperlukan untuk suatu bidang kerja seluas $A$ adalah (P.van.harten, Ir. E. setiawan:38).

Flux cahaya yang dipancarkan lampu-lampu tidak semuanya mencapai bidang kerja. Sebagian dan flux cahaya itu akan dipancarkan ke dinding dan langit-langit.
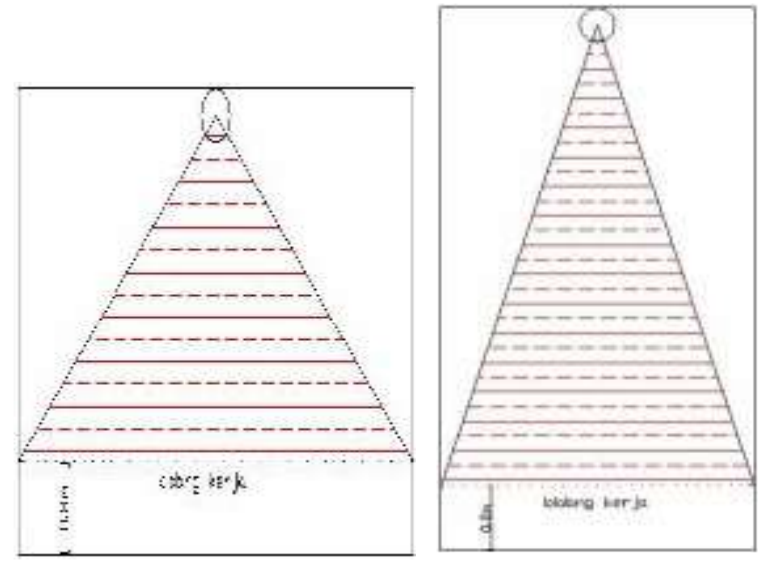

Gambar 7. Pembagian Flux Cahaya

Pada gambar 2.7 menunjukan pancaran cahaya yang dipancarkan oleh sebuah titik lampu kebidang kerja disuatu ruangan, dimana tinggi bidang kerja $80 \mathrm{~cm}$ atau kurang lebih 0,8 meter, tinggi lampu terhadap bidang kerja 4 meter $(\mathrm{t})$ dan tinggi langit-langit 3.2 meter $(\mathrm{h})$.

Untuk menghitung jumlah titik lampu pada ruangan, sebelumnya harus ditentukan terlebih dahulu data-data ruangan antara lain:

a. Tinggi langit langit (h)

b. Tinggi lampu terhadap bidang kerja $(\mathrm{t})$

c. Tinggi bidang kerja kurang lebih 0,8 meter

Sehingga didapat rumus

$H=t-0.8$ meter

$t=h-0.8$ meter

Dimana tinggi langit-langit pada ruang rapat, ruang arsip, mushola, dapur, koridor dan gudang adalah 4 meter dan tinggi lampu terhadap bidang kerja 3,2 meter (t) [3].

L. Indeks Ruang atau Indeks Bentuk

Indeks ruangan atau indeks bentuk $k$ menyatakan perbandingan antara ukuran-ukuran utama suatu ruangan berbentuk bujur sangkar.

Bidang kerja adalah suatu bidang horisontal khayalan, umumnya $0,80 \mathrm{~m}$ di atas lantai. Nilai $k$ yang diperoleh tidak terdapat dalam tabel efisiensi penerangannya dapat ditentukan dengan interpolasi. Misalnya $k=4,5$ maka efesiensi diambil nilai $k=4$ dan $k=5$. Untuk $k$ yang melebihi 5 diambil nilai efisiensinya hampir tidak berubah.

\section{Faktor Penyusutan/Depresiasi}

Intensitas penerangan $\mathrm{E}$ dalam keadaan dipakai adalah intensitas penerangan rata-rata suatu instalasi dengan lampu-lampu dan armatur-armatur, yang daya gunanya telah berkurang karena kotor, sudah lama dipakai atau sebab-sebab lainnya.

Faktor depresiasinya 0,8 suatu instalasi yang dalam keadaan baru 250 lux, akan memberikan hanya 200 lux saja dalam keadaan sudah terpakai. Jadi untuk memperoleh depresiasi penerangannya dalam keadaan terpakai dikalikan dengan efesiensi [2]. 
N. Menentukan Kapasitas Skering

Menentukan kapasitas skering/patron lebur atau pengaman pada pembagian tiap group (kelompok) instalasi listrik fasa satu dengan tegangan 220 Volt, maka arus yang mengalir Menentukan kapasitas patron lebur atau pengaman pada Pembagian Hubung Bagi (PHB) instalasi listrik fasa tiga dengan tegangan 380/220 volt.

\section{O. Susut Tegangan}

Susut tegangan atau rugi-rugi tegangan terjadi dikarenakan semangkin panjang kabel yang dibutuhkan maka akan terjadi susut tegangan pada penghantar tersebut. Oleh karena itu saluran utama terdiri dari hantaran dan mempunyai hambatan serta induktansi.

Sesuai dengan peraturan yang tercantum dalam Persayatan Umum Instalasi Listrik (PUIL) 2000, total rugi-rugi tegangan antara terminal dan pada titik beban pada instalasi listrik tidak boleh melebihi dari $2 \%$ [3].

\section{P. Pentanahan (Grounding)}

Pentanahan pengaman adalah suatu pengamanan dalam instalasi listrik yang rangkaiannya ditanahkan dengan cara mentanahkan badan peralatan yang diamankan. Pentanahan bertujuan untuk menghindari tegangan sentuh akibat tegangan berlebih. Proses pembumian dilakukan dengan cara menanam elektroda dalam tanah dengan kedalaman tertentu. Berdasarkan Persyaratan Umum Instalasi Listrik (PUIL) 2000 [3].

\section{- Elektroda Batang}

Elektroda ini dibuat dari pipa atau besi baja dengan panjang antara $80 \mathrm{~s} / \mathrm{d} 250 \mathrm{~cm}$. Elektroda jenis ini biasanya ditanam dengan kedalaman 1,5 s/d $6 \mathrm{~m}$. Jenis elektroda ini adalah jenis yang paling banyak digunakan dalam instalasi listrik.

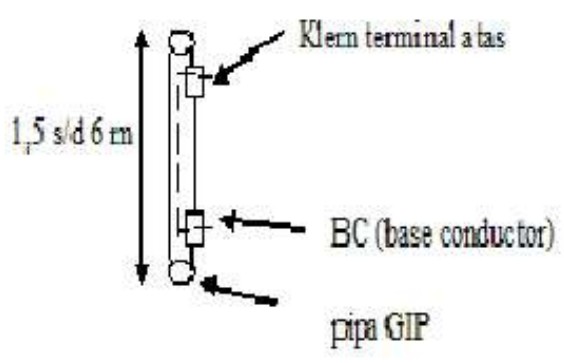

Gambar 2.8 Elektroda Batang

\section{Q. Biaya Optimasi}

Pada perencanaan instalasi listrik dengan menggunakan Solar Cell Sistem Hybrid dapat, diketahui dalam perhitungan, perbandingan biaya optimasinya antara menggunakan Solar Cell dan Sumber PLN.

Dalam pengoptimalan pemanfaatan Energi Module Photovoltaic, yang dapat menghasilkan energi listrik semaksimal mungkin, serta dapat mengurangi tagihan listrik rumah toko dan memberikan nilai tambah pada pemiliknya. Diasumsikan pada biaya optimasi dari sumber PLN10 = 2200 , dan Sollar Cell dengan modul surya $10=2200$ pada daya yang seimbang. Perencanaan dengan menggunakan Solar Cell pada lantai 1 Pada Modul Surya $10=2200$ berkapasitas $100 \times 24=1000(10$ $=2200$ ). Dalam 1 paket Sollar Cell dengan harga $=\mathrm{Rp}$
6.203.000,-. Jumlah Modul sebanyak 24 unit, dengan umur ekonomis pada Sollar Cell. Perencanaan dengan instalasi listrik pada lantai 1 perhitungan biaya optimasi dengan sumber PLN dengan daya $10 \mathrm{~A}=2200$ VA. Dalam pemakaian per bulan sebesar $425 \mathrm{kWh}$.

Pemakaian kWh perbulan x Daya terpasang

Biaya yang dikeluarkan setiap bulan

Pada "Perencanaan Instalasi Listrik Dengan Menggunakan Hybrid" Dapat diperhitungkan biaya optimasinya, dengan diketahui besar selisih biaya pemakaian perbulannya dari $=-$ Sollar Cell .

\section{METODE PENELITIAN}

\section{A. Kerangka Konsep Perencanaan}

Kerangka konsep perencanaan instalasi listrik dengan menggunakan Hybrid ini adalah dalam bentuk diagram alir seperti pada gambar 3.1. Pada diagram alir dijelaskan tentang dari perencanaan instalasi listrik adalah menghitung kapasitas modul, menghitung kapasitas baterai, menghitung jan keja matahari, menghitung besarnya radiasi matahari, menghitung luas ruangan, menghitung indeks ruang,menghitung jumlah titik baban (lampu), menghitung kemampuan sekring tiap lantai, menghitung penampang kabel, menghitung rugi-rugi tegangan dan menghitung pentanahan (graonding) pada denah rumah toko yang akan dikerjakan.

\section{B. Variabel Perencanaan}

Variabel perencanaan instalasi listrik yang digunakan ini adalah dengan menggunakan dua sumber yaitu dengan menggunkan hybrid dan sumber dari PLN. Serta menghitung luas setiap ruangan, beban lampu setiap ruang, kapasitas sekering tiap lantai, luas penampang kabel/penghantar, susut tegangan dan pentanahan (Grounding).

\section{HASIL DAN PEMBAHASAN}

\section{A. Perhitungan Total Daya Ruko}

Untuk perencanaan instalasi listrik dengan menggunakan Solar Cell Sistem Hybrid, terlebih dahulu harus diketahui total daya pada ruko dengan menghitung secara terpisah tiap tiap ruangan.

Berdasarkan hasil perhitungan didapatkan data nilai daya untuk 3 lantai ruko pada Tabel I :

Tabel I

\begin{tabular}{|c|c|c|}
\hline \multicolumn{3}{|c|}{ Rincian Daya Tiap Lantai } \\
\hline No & Lantai & Daya (VA) \\
\hline 01 & I & 2100 VA \\
\hline 02 & II & $2100 \mathrm{VA}$ \\
\hline 03 & III & 4592 VA \\
\hline \multicolumn{2}{|c|}{ Total } & 8792 VA \\
\hline
\end{tabular}

Dengan rincian perhitungan daya tiap lantai pada Tabel II dibawah : 
Tabel II

Perhitungan Daya Tiap Lantai

\begin{tabular}{|c|c|c|c|c|c|c|c|c|c|c|c|}
\hline \multirow[b]{2}{*}{ No } & \multirow[b]{2}{*}{ Ruang } & \multirow[b]{2}{*}{ K } & \multirow[b]{2}{*}{$\begin{array}{c}\mathrm{A} \\
\left(\mathrm{m}^{2}\right)\end{array}$} & \multirow[b]{2}{*}{ E } & \multirow[b]{2}{*}{$\mathrm{H}$} & \multirow[b]{2}{*}{$\mathrm{n}$} & \multirow[b]{2}{*}{$\mathrm{d}$} & \multirow[b]{2}{*}{$\phi$} & \multirow{2}{*}{$\begin{array}{c}\text { Stop } \\
\text { kontak/ } \\
\text { KKB }\end{array}$} & \multicolumn{2}{|c|}{ Jenis lampu } \\
\hline & & & & & & & & & & $\begin{array}{l}\text { TL (watt) } \\
2 \text { x } 40 \text { watt }\end{array}$ & $\begin{array}{l}\begin{array}{l}\text { SL } \\
\text { (watt) }\end{array} \\
18 \\
\text { watt }\end{array}$ \\
\hline Lantai I & Tempat Barang & 2,8 & 340 & 250 & 0,532 & 40 & 0,8 & 2500 & 2 & 40 & \\
\hline Lantai II & Tempat gudang & 2,8 & 340 & 250 & 0,532 & 40 & 0,8 & 2500 & 2 & 40 & \\
\hline \multirow{11}{*}{ Lantai III } & Makan/Dapur & 0,8 & 24 & 150 & 0,33 & 4 & 0,8 & 2500 & 1 & 4 & \\
\hline & Ruang Tamu & 0,8 & 24 & 150 & 0,33 & 4 & 0,8 & 2500 & 2 & 4 & \\
\hline & Ruang keluarga & 0,8 & 24 & 150 & 0,33 & 4 & 0,8 & 2500 & 2 & 4 & \\
\hline & Kamar tidur 1 & 0,93 & 36 & 150 & 0.36 & 4 & 0,8 & 2500 & 2 & 4 & \\
\hline & Kamar tidur 2 & 0,93 & 36 & 150 & 0,36 & 4 & 0,8 & 2500 & 2 & 4 & \\
\hline & Administrasi & 0,96 & 40 & 1000 & 0,37 & 6 & 0,8 & 2500 & 1 & 6 & \\
\hline & Kamar mandi 1 & 0,37 & 6 & 50 & 0,24 & 1 & 0,8 & 900 & - & - & 1 \\
\hline & Kamar mandi 2 & 0,37 & 6 & 50 & 0,24 & 1 & 0,8 & 900 & - & - & 1 \\
\hline & Kamar Wc 1 & 0,312 & 4 & 50 & 0,24 & 1 & 0,8 & 900 & - & - & 1 \\
\hline & Kamar Wc 2 & 0,312 & 4 & 50 & 0,24 & 1 & 0,8 & 900 & - & - & 1 \\
\hline & Koridor & 0,93 & 36 & 50 & 0,36 & 12 & 0,8 & 2500 & 2 & 12 & \\
\hline Total & & & - & - & & 122 & - & - & 16 & 106 & 4 \\
\hline
\end{tabular}

\section{B. Biaya Optimasi}

Perencanaan instalasi listrik dengan menggunakan Solar Cell Sistem Hybrid dalam perhitungan biaya optimasinya, dapat diasumsikan pada sumber PLN $10 \mathrm{~A}=$ 2200 VA, dan Solar Cell dengan modul surya 10A $=2200$ VA dengan daya yang seimbang dan disesuaikan pada kebutuhan.

Perencanaan dengan menggunakan Solar Cell pada lantai 1, pada Modul Surya $10 \mathrm{~A}=2200 \mathrm{VA}$, berkapasitas $100 \mathrm{Wp}$ x $24=1000(10 \mathrm{~A}=22000 \mathrm{VA})$. Dalam 1 paket Sollar Cell, diasumsikan dengan kisaran harga $\mathrm{Rp}$ 6.203.000,-. Dengan jumlah modul sebanyak 24 unit, umur ekonomis pada Sollar Cell sebesar 15 tahun.

Untuk menghitung biaya perbulan selama 1 tahun adalah dengan membagi total harga keseluruhan modul yang digunakan dengan umur ekonomis dalam 1 tahun. Sehingga didapatkan biaya perbulan sebesar Rp 827.067,-

Diasumsikan dalam perhitungan biaya optimasinya, perencanaan instalasi listrik pada lantai 1 dengan sumber PLN dengan daya $10 \mathrm{~A}=2200 \mathrm{VA}$. Dalam pemakaian per bulan sebesar $425 \mathrm{kWh}$. Sehingga biaya yang dikeluarkan perbulan adalah hasil dari perkalian pemakaian per bulan dengan daya terpasang, sehingga didapatkan biaya sebesar Rp 935.000,-. Maka diketahui selisih biaya perbulannya dengan cara menghitung selisih antara biaya pemakaian pada PLN dengan biaya pemakaian pada Sollar Cell. Didapatkan selisih sebesar Rp 107.933,perbulan.

\section{KESIMPULAN}

Dari hasil perhitungan pada perencanaan instalasi listrik dengan menggunakan Hybrid, didapat bahwa jumlah titik beban berupa lampu pada:

a. radiasi matahari terbesar pada bulan April, sehingga besarnya energi yang dihasilkan dari radiasi matahari yang masuk kemodul sebesar $0,708 \mathrm{~kW}$ atau $708 \mathrm{~W}$, jumlah jam kerja matahari $3,547 \mathrm{~h}$, kapasitas daya modul 1705,66 Wp dan jumlah modul 10.

b. Jumlah beban berupa lampu pada lantai I sebesar 40 watt, lantai II 40 watt dan pada lantai III 60 watt.

c. Besarnya pengaman/MBC pada lantai I 16 ampere, lantai II 16 ampere dan pada lantai III 25 ampere.

d. Diameter pada kabel yang digunakan pada perencanaan instalasi pada rumah toko (ruko) adalah $2,5 \mathrm{~mm}$, susut tegangan $38,74 \%$ serta pentanahan pada instalasi $1,5 \mathrm{ohm}$. Pemakaian untuk biaya dengan menggunakan hybrid adalah sebesar Rp 827.067,- dan untuk pemakaian dengan menggunakan PLN sebesar Rp 935.000,-. Maka selisih untuk pemakaian perbulannya adalah sebesar Rp 107.933,-.

\section{REFERENSI}

[1] Irwan Yulistiono., Ir. Teguh Utomo, MT., Ir. Unggul Wibawa, M.Sc.

[2] P. van. Harten, ir. E. Setiawan, 1991. Insatalasi Listrik Arus Kuat Jilid 1 Percetakan Binacipta Bandung.

[3] Persyaratan Umum Instalasi Listrik 2000 (PUIL 2000)/ Standar NasionalIndonesia (SNI). 